\title{
HIV-1 subtype B- and F1-infected subjects display higher cross-clade T-Cell response than subtype C-infected subjects
}

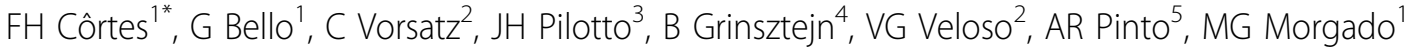 \\ From AIDS Vaccine 2012 \\ Boston, MA, USA. 9-12 September 2012
}

\section{Background}

The impact of the extensive genetic diversity of the HIV-1 group $M$ isolates and its implications for vaccine design have long been discussed. Studies indicate that Gag and Nef conserved epitopes are commonly recognized and give rise to high cross-clade responses. The aim of this study was to compare $\mathrm{T}$-cell responses to peptide pools derivate from subtype $\mathrm{B}, \mathrm{C}$ and $\mathrm{F} 1$ consensus, among Brazilian subjects infected with those three HIV-1 subtypes.

\section{Methods}

The study included 32 subjects infected with HIV-1 subtypes B $(n=13), C(n=11)$ and F1 $(n=8)$. Gag and Nefspecific $\mathrm{T}$ cell responses were evaluated by IFN- $\gamma$ ELISpot assay, using peptide pools based on subtype B, C and F1 Brazilians consensus.

\section{Results}

A high cross-clade response between subtypes B and F1 for both Gag and Nef regions was observed among HIV-1 subtype B- and F1-infected subjects. We also found no significant difference in magnitude of responses between subtype $\mathrm{B}$ and $\mathrm{C}$ consensus peptides in subtype $\mathrm{B}$-infected subjects.In contrast, the magnitude of $\mathrm{T}$ cell responses to consensus $\mathrm{C}$ peptides in Gag region was significantly higher than to consensus B peptides among HIV-1 subtype C-infected subjects. In Nef, subtype C-infected subjects showed higher $\mathrm{T}$ cell responses to $\mathrm{C}$ than to $\mathrm{F} 1$ consensus peptides. Moreover, subtype F1-infected subjects presented lower responses to subtype $C$ peptides than to subtype F1 and B ones.

${ }^{1}$ Oswaldo Cruz Institute/FIOCRUZ, Rio de Janeiro, Brazil

Full list of author information is available at the end of the article

\section{Conclusion}

Overall, the level of cross-clade response between subtypes $B$ and F1 was higher than between subtype $C$ and $B$ or between subtype $C$ and F1. Our data suggest that significance of the HIV-1 group $M$ genetic diversity for vaccine design may be dependent of the subtypes involved.

\section{Author details}

'Oswaldo Cruz Institute/FIOCRUZ, Rio de Janeiro, Brazil. "2Evandro Chagas Clinical Research Institute/FIOCRUZ, Rio de Janeiro, Brazil. ${ }^{3}$ Nova Iguaçu General Hospital, Nova Iguaçu, Brazil. ${ }^{4}$ Evandro Chagas Clinical Research Institute/FIOCRUZ, , Rio de Janeiro, Brazil. ${ }^{5}$ Department of Microbiology, Immunology and Parasitology/UFSC, Santa Catarina, Brazil.

Published: 13 September 2012

doi:10.1186/1742-4690-9-S2-P150

Cite this article as: Côrtes et al: HIV-1 subtype B- and F1-infected subjects display higher cross-clade T-Cell response than subtype Cinfected subjects. Retrovirology 2012 9(Suppl 2):P150.

Submit your next manuscript to BioMed Central and take full advantage of:

- Convenient online submission

- Thorough peer review

- No space constraints or color figure charges

- Immediate publication on acceptance

- Inclusion in PubMed, CAS, Scopus and Google Scholar

- Research which is freely available for redistribution 